\title{
Breast Cancer pT1 TNM Finding v6 and v7
}

National Cancer Institute

\section{Source}

National Cancer Institute. Breast Cancer pT1 TNM Finding v6 and v7. NCI Thesaurus.

Code C48978.

Breast cancer with tumor size $2.0 \mathrm{~cm}$ or less in greatest dimension. (from AJCC 6th and 7th Ed.) 